Igneous Minerals and Rocks

By Ernest E. Wahlstrom. Pp. ix + 367. (New York: John Wiley and Sons, Inc.; London : Chapman and Hall, Ltd., 1947.) 33s. net.

7 HIS book is intended for two classes of reader, namely, the student beginning the study of the igneous rocks, and the geologist seeking a refresher course. As a result, the beginner will need careful guidance in his selection of the essentials from the mass of information presented for the expert. Either class of reader is assumed to have a good knowledge of optical mineralogy, presumably from the author's "Optical Crystallography".

In the first part of the work, the minerals, including these of contamination and alteration origin, that make up the igneous rocks are described in detail and illustrated by excellent photographs of thin sections. Adequate accounts are given of all the techniques used in minerel identification, and the author emphasizes the importance of not relying on thin section examine. tion only. The test of this kind of instruction is the manner of treatment of the identification of the plagioclase felspars-the author passes the test with ease. This part of the book contains tables for the identification of minerals in thin section and by the use of immersion media.

In Part 2 the igneous rocks are dealt with. A brief account of their geological occurrence is first presented. It may be noted that here the author, forgetting the etymology of the good English word, uses 'dyke' in an unusual sense. He decides that rocks can be classified wholly on the basis of their mineral composition and-texture, so that genetic considerations are neglected. Some results are, for example, the separation of quartz-dolerites and quartzgabbros from the dolerites and gabbros, and the placing of granite and rhyolite in one family. His compromise classification is semi-quantitative, the main divisions, six in number, being based on the presence of the following minerals: felspars and silica minerals; felspars; felspars with less felspathoids; felspathoids with less felspar; felspathoids; ferromagnesian minerals. Photographs of hand specimens and thin sections of igneous rocks are provided, and also an outline scheme for the identification of the igneous rocks under the microscope. Much of the book reads like a lexicon but, with petrogenesis deliberately excluded, that is to be expected. Here is, at least, an excellent petrographic lexicon.

H. H. R.

\section{Electric-Motor Control Gear : Starting, Protection and Speed}

By J. L. Watts. Pp. 96. (London : Iliffe and Sons, Ltd., 1948.) 5s. net.

$\mathrm{T}$ HIS book is arranged in the form of notes on motors and control gear, and contains a lot of useful information in a small space. It is intended chiefly for electricians engaged in the maintenance and installation of such plant. No attempt is made to cover any aspects of design, but starting conditions and their effect on acceleration and control gear are discussed briefly, graphical examples being given for squirrel-cage and slip-ring motors. A valuable feature is the inclusion of speed-torque characteristics of various types of single-phase motors. There is a useful chapter on protective gear, and the final chapter gives examples of connexions of typical control gear for D.o., single-phase and three-phase motors.
There are a number of imperfections which should be rectified before the book is reprinted. For example, the obsolete symbol $C$ is used for current, $F$ for power factor, and a queer nameless symbol is used for flux instead of the usual $\Phi$. Symbols and abbrevi. ations are all printed in Roman type, and in consequence $V$ appears both as a symbol and an abbreviation. Non-standard British Standards Specification terms are also used, such as capacity (instead of capacitance), no-volt release (instead of under. voltage release), overload release (instead of over. current release). Some weird mathematicel ex. pressions also occur, such as $\frac{230 \mathrm{~V}}{13 \Omega}=17 \cdot 7 \mathrm{~A}$.

Some of the diagrams relating to motor characteristics and speed control require more explanation, for example, Figs. 15, 16, 17, 46, 49, and some connexion diagrams require revision.

A. T. D.

La vie des requins

Par P. Budker. (Histoires naturelles, 7.) Pp. $278+$ 22 plates. (Paris : Libr. Gallimard, 1947.) 325 francs.

7 HIS small volume is admirable in its simplicity and interest the secret of its success being the author's undoubted liking, if not affection, for these huge sharks which are regarded with horror and disgust by many. The subject is approached with respect for the shark and admiration for its wonderful power and form, so perfectly fitted for its mode of life. Certainly a dogfish swimming in an aquarium tank is an unforgettable sight. The numerous illustrations are good, both plates and text figures, and the various chapters cover much ground: classification, morphology, anatomy, food habits and 'les mangeurs d'homme', freshwater sharks, pilots and remoras, history, and shark fisheries and utilization. As man-eaters the large sharks are apparently much less dangerous than is usually supposed. They undoubtedly eat man, especially in certain regions, but they are easily frightened, and it has been stated that they are the most cowardly of all animals that fly, run or swim. This is No. 7 of a series of "Histoires naturelles", and is thoroughly recommended to all lovers of natural history.

\section{Nature and Prevention of Plant Diseases}

By Dr. K. Starr Chester. (Blakiston Books on Agriculture.) Second edition. Pp. xi + 525. (London : H. K. Lewis and Co., Ltd., 1947.) 25s. net.

$7 \mathrm{HE}$ second edition of Dr. K. Starr Chester's well-known introductory text-book on plant pathology is extensively revised, and an eight-page glossary has been added. The chapters on bacterial and virus diseases have considerable additions. In some other chapters the text has been successfully pruned to improve the balance of the presentation. Chapter 20, on the control of plant diseases, contains a valuable tabulation of new fungicides, and an account of such recent methods of seed disinfection as the slurry and pelleting treatments. The work is intended for American students, and more than 90 per cent of the references to literature are North American.

The book omits mention of some of the major crop diseases of Britain, including virus yellows of sugar beet, and the take-all (Ophiobolus) and eyespot (Cercosporella) diseases of wheat. Lodging of wheat is described as primarily a light-deficiency disease. However, the book might be used as a text in Great Britain if judiciously amended. 